\title{
El patrimonio religioso inmaterial de las Órdenes religiosas en Andalucía ${ }^{1}$
}

\author{
SALVADOR RODRÍGUEZ BECERRA \\ Universidad de Sevilla
}

Resumen: Las órdenes religiosas mendicantes desde su fundación en Andalucía en el siglo XIII y especialmente durante su amplia expansión durante los siglos XVI y XVII, fueron creando un patrimonio material e intangible que, aunque disminuido y modificado, ha llegado a nosotros. Este patrimonio se puede ver en los rituales, devociones y actitudes que sobreviven en la religiosidad popular, expresión del patrimonio religioso inmaterial. El patrimonio inmaterial que produjeron las órdenes religiosas permaneció entre el pueblo, ahora administrado por el clero parroquial, hermandades y cofradías y congregaciones que lo mantuvo en gran parte y que ha conformado la religiosidad popular o común de los andaluces. Los efectivos humanos de las órdenes fueron transferidos al clero diocesano, sus templos y enseres a las diócesis, y sus bienes materiales nacionalizados y sacados a pública subasta o, transferidos a los municipios que los usaron con diversos fines.

Palabras clave: Órdenes religiosas, patrimonio inmaterial, religiosidad popular, devociones, Andalucía.

Summary: The mendicant religious orders since its establishment in Andalusia in the thirteenth century and especially during its wide expansion during the sixteenth and seventeenth centuries, were creating a material and intangible heritage that, although very diminished and modified has come

${ }^{1}$ Agradezco a los profesores José Luis Alonso Ponga, Salvador Hernández González y Francisco Javier Quintana sus sugerencias al texto. 
to us. This heritage can be seen in the rituals, devotions and attitudes that survive in popular religiosity, expression of intangible religious heritage. The Intangible heritage remained among the people, now administered by the parish clergy that largely maintained it and constitute the popular or common religiosity of the Andalusians. The human enforcement of the orders was transferred to the diocesan clergy, their temples and belongings to the dioceses, and their material goods nationalized, taken out for public auction or, transferred to the municipalities that used them for various purposes.

Key words: Religious orders, intangible heritage, popular religiosity, devotions, Andalusia.

\section{Introducción}

En los últimos tiempos encontramos muchos trabajos de investigación dedicados a la recuperación del patrimonio religioso material, aunque solo sea para su conocimiento, que ya es una forma de recuperación, pues gran parte de él ha desaparecido. Este patrimonio fue creado y mantenido por las órdenes religiosas durante casi quinientos años o más, gracias a las aportaciones de los creyentes. Durante los siglos XIX y XX este patrimonio artístico y monumental sufrió graves daños y mermas como consecuencia de decretos de exclaustración y desamortización, motines o simplemente por la incuria del tiempo. La pérdida de patrimonio es muy notoria por el alto valor artístico de las obras pues los conventos contrataban a los mejores maestros de cada momento. No ha ocurrido lo mismo con el patrimonio inmaterial o intangible formado por las creencias, rituales e instituciones, creadas o impulsadas por las órdenes. Los historiadores e historiadores del arte le han dedicado hasta ahora escasa atención o, en todo caso, se han ocupado de este patrimonio de forma tangencial. Este patrimonio que también sufrió los avatares de ilustrados, liberales y descreídos y en tiempos más recientes de la secularización, se ha mantenido en gran parte y expresa su religiosidad, forma que muchos andaluces tienen de relacionarse con los seres sobrenaturales ${ }^{2}$. Esta religiosidad que

\footnotetext{
${ }^{2}$ Rodríguez Becerra, S., "Nuevas perspectivas sobre la religiosidad popular o religión común de los andaluces”, en: F. Checa Olmos y C. Jiménez de Madariaga (coords.), Gazeta de Antropología, 28 (3) 2012.
} 
cristalizará en el Barroco constituye la gran aportación de las órdenes religiosas que, abocadas a vivir con sus propios medios y capacidades, al tiempo que ejercían su apostolado, imprimieron en la sociedad una peculiar forma de vivir y sentir la religión, sin obviar otros condicionantes socioeconómicos y culturales propios de la región andaluza ${ }^{3}$.

Las diócesis andaluzas en el Antiguo Régimen, tiempo en que se conforma la religiosidad, presentaban una clara debilidad estructural para los objetivos que teóricamente se proponían frente a las órdenes religiosas que llegaron a estar más presentes e involucradas socialmente, al no estar sostenidas con los presupuestos públicos -diezmos y patrimonio-y actuar como revulsivo frente a una iglesia jerárquica, estamentalizada y burocratizada desde sus orígenes y en las sucesivas reformas ${ }^{4}$. El clero parroquial, aunque numeroso, pero poco motivado, estaba mal pagado dado que los ingresos del diezmo, sin duda los mayores, se dedicaban al obispo, al cabildo catedral y a los beneficiados parroquiales, generalmente absentistas y que carecía de obligaciones pastorales. Se favorecieron hasta finales del XVIII en que se iniciaron algunas reformas los derechos individuales de los beneficiados sobre los de los curas y los intereses colectivos. La cura de almas que implicaba sobre todo la administración de los sacramentos recaía sobre los curas que eran pocos y apenas tenían acceso a estos bienes. En todo caso, la iglesia diocesana creemos que era vista por el común como una institución más del Estado porque entre otras cosas, cobraba impuestos y tenía tribunales de justicia propios. Los capellanes vivían casi exclusivamente de las capellanías y obras pías, dotadas con bienes y rentas por los fundadores para que se dijeran misas por su alma y por las de sus antepasados. Por el contrario, los conventos tenían una amplia presencia tanto en las grandes ciudades como en las pequeñas mediante las predicaciones y confesiones y otros rituales cubriendo así las necesidades espirituales del conjunto salvo los sacramentos esenciales como el bautismo y el matrimonio, reservados en exclusiva a las parroquias.

${ }^{3}$ Rodríguez Becerra, S. y Hernández González, S., "Las órdenes religiosas y la religiosidad durante el Barroco", en: Congreso Internacional Andalucía Barroca: IV. Ciencia, Filosofía y Religiosidad. Actas, Sevilla: Consejería de Cultura. Junta de Andalucía 2008, 171-195.

${ }^{4}$ Rodríguez Becerra, S. y Hernández González, S., "La Religiosidad Popular y los mendicantes en Andalucía en el Antiguo Régimen”, en: M. Peláez del Rosal (Ed.), Aportaciones al Diccionario Biográfico Franciscano de España, Portugal, Iberoamérica y Filipinas. Actas Cursos de Verano XVII-XIX, Córdoba: AHEF 2014, 425-468. 


\section{El proceso de transferencia del patrimonio inmaterial o espiritual}

Las órdenes religiosas todas en general y cada una de ellas en particular han aportado al cristianismo una especial forma de espiritualidad, o lo que es lo mismo, una peculiar y matizada valoración de los misterios y el sentido de lo religioso, expresado en rituales: vía crucis, coronas de la virgen, jubileos, Semana Santa, rosarios de la aurora, novenas, etc.; también en la promoción y difusión de la devoción a imágenes específicas: titulares de órdenes, advocaciones enraizadas en la geografía local -las imágenes marianas más reconocidas lo fueron por la acción de los frailes- y santos fundadores y propios de los institutos conventuales. Igualmente, promovieron la creación de asociaciones religiosas entre seglares, tales como hermandades y órdenes terceras; difundieron el uso de símbolos: escudos, medallas, escapularios, banderas, guiones; crearon espacios sagrados, como calvarios, capillas callejeras, ermitas, santuarios y desde luego, determinaron espacios urbanos con sus conventos, iglesias, claustros, enfermerías, huertos, etc. En síntesis, las órdenes religiosas aportaron a la religión común de los andaluces que cristaliza en el barroco un conjunto de rituales, instituciones, imágenes, edificios y espacios que en el siglo XIX fueron transferidas a las iglesias diocesanas y a las sociedades locales ${ }^{5}$. Esto que puede decirse para toda España es especialmente marcado en Andalucía donde las órdenes tuvieron tanta y tan influyente implantación.

Sabido es que muchos frailes, padres y legos tras la exclaustración quedaron de la noche a la mañana en la calle y sin medios para subsistir, por lo que los legos se marcharon a sus casas o buscaron trabajo manual en el entorno conventual, los padres puesto que eran presbíteros o sacerdotes recibieron una pequeña pensión que no siempre llegaba o buscaron acomodo como capellanes de cofradías, congregaciones, ermitas y familias pudientes, o fueron ocupados por la administración diocesana y parroquial como tenientes de cura y en otros oficios eclesiásticos; otros fueron acogidos como preceptores de familias poderosas ${ }^{6}$ o abandonaron la vida

${ }^{5}$ Cortés Peña, A. L., "La Iglesia y la religiosidad”, en: F. Andújar Castillo (coord.), Historia del Reino de Granada, vol. 3, Granada: Universidad de Granada 2000, 489-530.

${ }^{6}$ Fernán Caballero en su novela La Estrella de Vandalia (1855) novela autobiográfica que sitúa en Carmona, refiere en el capítulo segundo el caso de un monje jerónimo exclaustrado que fue acogido como preceptor de los hijos de una distinguida familia de la ciudad. 
eclesiástica. Los templos conventuales fueron dedicados a parroquias o ayudas de parroquias, por traslado de las ruinosas o de nueva creación, -los edificios muestran signos externos e internos de su primitiva pertenencia-, otros permanecieron abiertos porque en ellos residían imágenes de gran devoción donde encontraron acomodo como capellanes algunos frailes, pero otros tantos por falta de función fueron cerrados. Algunos de los edificios que no fueron dedicados al culto lo fueron a otras tantas funciones de forma permanente o esporádica, desde la utilización como hospitales en casos de guerra o epidemias hasta refugio de pobres y damnificados. Hacer relación de las iglesias conventuales y conventos que se vieron afectados por los decretos desamortizadores sería interminable. El conocido Diccionario geográfico-estadístico de España y Portugal (1840-1850) de Pascual Madoz recoge en la mayoría de los casos la suerte que siguieron estos edificios por haberse elaborado esta obra poco después de estos dramáticos sucesos?

Pero con anterioridad a la exclaustración las órdenes religiosas ya habían conformado la religiosidad en la forma más que en el fondo porque esta era tributaria de los valores de una sociedad estamental -con pocos

${ }^{7}$ A título de ejemplo y tratando de cubrir el ámbito andaluz, las distintas órdenes y mi interés personal, cabe citar: la iglesia conventual de los franciscanos de Palma del Río convertida en parroquia con el título de San Francisco en 1954 tras pasar por ayuda de parroquia y otros diversos usos, la de los dominicos de Guadix como San Miguel, la de los carmelitas de Aracena como del Carmen, la de los franciscanos terceros regulares de Alcalá la Real como Consolación, la de los dominicos como Santo Domingo en Cabra, de los carmelitas como San Andrés en Málaga, la de los clérigos menores de San Francisco Carracciolo como parroquia de Santa Cruz en Sevilla, la de los dominicos como Santo Domingo de Osuna, la de los terceros franciscanos regulares como de Consolación también en Osuna, la de los mínimos de Morón de la Frontera como de la Victoria, la de los mínimos de Conil de la Frontera en la de Santa Catalina o el colegio de San Teodomiro de los jesuitas de Carmona que acogió a la parroquia del Divino Salvador. Los templos conventuales que no se constituyeron en parroquias, pero eran necesarios para el culto, quedaron al cuidado de algún fraile exclaustrado que daba servicio religioso, generalmente a una población diseminada, como ocurriera con el padre Manolito, nombrado capellán diocesano de la iglesia del convento de Loreto (Espartinas), evitando así el saqueo y la ruina del conjunto patrimonial por estar en un descampado. Otro tanto podría decirse del carmelita del convento o desierto de El Juncal (Algodonales) que fue nombrado capellán de la cercana aldea de La Muela, núcleo surgido al amparo del propio convento, que como era de esperar siguió dando culto a la virgen del Carmen que posteriormente fuera nombrada titular de la parroquia que allí se creara. 
nobles y muchos servidores, criados y dependientes-, campesina y depauperada en la que unos pocos gozaban de muchos privilegios mientras que la mayoría carecía de lo más elemental. En este sentido las devociones y las ceremonias más generalizadas entre andaluces eran las que los frailes mendicantes habían conseguido introducir en las mentes de las élites y el pueblo, sin duda por su cercanía catequética a ambos sectores sociales $-\mathrm{y}$ aquí pueden estar algunas de las claves fundamentales de su éxito-, las cuales han llegado hasta nuestros días. Los rituales y devociones que aportaron los frailes convivieron con los dedicados a las imágenes marianas y cristíferas propias de cada localidad, las cuales estaban enraizadas por leyendas de aparición y hallazgo y con las que se identifican plenamente hasta el punto de que aquellas llegaron a simbolizar al conjunto de la población. En cuanto a las organizaciones religiosas de laicos, las hermandades y cofradías que tanta presencia y fuerza han tenido y tienen en Andalucía, contaron siempre con el apoyo de las órdenes religiosas que las albergaron en sus conventos y sostuvieron ritualmente a cambio de contraprestaciones económicas.

El hecho de que las imágenes de la virgen del Carmen y del Rosario y la de san Antonio estén presentes en todas las iglesias parroquiales, el que haya sido reconocido su patronazgo por numerosos pueblos de Andalucía y el que los nombres de persona como los de Carmen, Rosario, Mercedes o Dolores estén entre los más comunes entre mujeres y el de Antonio entre hombres es indicativo de esta poderosa influencia en el pasado. Pero, además, muchas de las imágenes marianas más enraizadas en algunas localidades, regidas habitualmente por hermandades, han estado en algún momento de su historia custodiadas por órdenes mendicantes o monacales o ellos mismos fueron los creadores de la tradición ${ }^{8}$. No obstante, la devoción a ciertas imágenes que gozaron en otro tiempo de gran devoción y atractivo, auspiciadas por los frailes, ha disminuido o se ha perdido cuando estos faltaron ${ }^{9}$,

${ }^{8}$ Así, con anterioridad a la exclaustración los jerónimos fueron los custodios de la virgen del Valle (Écija); los mínimos de la virgen de Consolación (Utrera) y de la Victoria (Málaga) y durante un cierto tiempo de la del Rocío (Almonte); los franciscanos terceros regulares de la virgen de Caños Santos (hoy en Cañete la Real), los franciscanos de la Rábida de la de los Milagros (Palos de la Frontera), los agustinos de la de Regla (Chipiona) y los dominicos de la virgen del Mar (Almería). Igualmente, de forma indirecta los franciscanos contribuyeron al auge de la virgen de Belén (Palma del Río), cuya advocación era la del convento antes de que se generalizara el título de san Francisco. 
salvo que tras el abandono estas imágenes fueran trasladadas a las iglesias mayores y allí entronizadas ${ }^{10}$. Como consecuencia sus primitivos emplazamientos, especialmente ermitas, se han ido depauperando o destruyendo, aunque los vecinos los recuperan una vez al año con la celebración de romerías.

En el siglo XVIII, aunque la capacidad de influencia y potencia demográfica de las órdenes religiosas se mantiene, hay indicios de cierta decadencia en las mendicantes y monacales que viene expresada por la incapacidad de los conventos por mantener a los frailes en el claustro hasta el punto de que algunos vivían habitualmente fuera de los conventos y ejercían como sustitutos de curas y beneficiados y otros cargos eclesiásticos. En el interior de los conventos se hicieron presentes actitudes contrapuestas entre conservadores y liberales con la relajación de la regla que ello llevaba aparejada de suerte que la disciplina y la obediencia se vieron seriamente afectadas. Al descrédito en que habían caído los frailes se unió el deseo de los gobernantes, especialmente durante los reinados de Carlos III y Carlos IV, de hacerse con su patrimonio y reducir el número de frailes y conventos. El siglo XIX traerá el sometimiento de los frailes a la autoridad de los obispos y las exclaustraciones. Este proceso, iniciado por las medidas dictadas por el gobierno de José I Bonaparte, recibirá el definitivo golpe con la legislación desamortizadora del gobierno de Mendizábal durante la regencia de María Cristina de Borbón-Dos Sicilias, medidas encaminadas a resolver la guerra civil carlista y la deuda pública.

\footnotetext{
${ }^{9}$ El Cristo de San Agustín de gran devoción en Sevilla mientras estuvo al cuidado de los agustinos calzados en su convento casa grande de Sevilla perdió el atractivo devocional tras la exclaustración, aunque una nueva imagen con la misma advocación ha sido recuperada como cotitular por la Cofradía de San Roque, parroquia donde fue recogida la imagen original destruida en los sucesos de 1936. Algo semejante ocurrió con la Virgen del Pópulo, que llegó a ser titular del convento de los agustinos recoletos de la misma ciudad, sustituyendo al original de santa Mónica, dada la popularidad que como milagrosa alcanzó la imagen de la Virgen pintada en un cuadro. La presencia de la imagen en Sevilla, aunque de reminiscencias romanas, está ligada a leyendas milagrosas surgidas en la ciudad a raíz de la inundación de 1626 y a las que no debieron ser ajenos los propios frailes. Otro tanto ha ocurrido con la Virgen de las Veredas de los franciscanos (Utrera), la de Consolación de los terceros conventuales de Morañina (Bollullos del Condado), la de la Victoria en los mínimos de Triana (Sevilla) y la de los Remedios de los carmelitas descalzos del mismo barrio.

${ }^{10}$ Tal sucedió entre otras con la virgen de Gracia de Carmona, patrona de la localidad, entronizada en la iglesia mayor prioral o con la virgen de Aguas Santas, patrona de Villaverde del Río que fue instalada en una capilla de la iglesia parroquial.
} 
A pesar de lo dicho el siglo XVIII conocerá desde el comienzo la explosión de los rosarios públicos que tan presentes han estado en la vida religiosa hasta el último tercio del siglo XX. Así mismo hay que considerar el caso del capuchino fray Diego José de Cádiz, verdadera figura estelar del último tercio del citado siglo, predicador incansable, apasionado y convincente y con tal capacidad de convocatoria que sus misiones y visitas se convertían en un problema de orden público. Este recorrió toda Andalucía predicando la versión tradicionalista del cristianismo oponiéndose a las ideas de la Ilustración y al progreso que preconizaba la Sociedad Económica de Amigos del País, lo que supuso un revulsivo de conservadurismo para la sociedad y el intento de detener el camino del liberalismo.

La nueva entrada de las órdenes religiosas en España tuvo lugar como consecuencia de la firma del Concordato de 1851 durante el reinado de Isabel II y el gobierno de Bravo Murillo, que entre otros acuerdos reafirmó la confesionalidad católica del Estado y la reorganización de las diócesis y se abrió la puerta para el regreso de las órdenes religiosas. El ideal de las órdenes a su regreso fue conseguir los mismos conventos e iglesias que habían ocupado antes de la exclaustración y que no habían sido demolidos, pero ello no siempre fue posible dado que estos bienes -sobre todo edificios conventuales y huertas- ya tenían nuevos propietarios legítimos. No obstante, las órdenes mendicantes consiguieron la custodia de algunos santuarios, así los franciscanos se hicieron cargo del santuario de Linarejos (Linares), los trinitarios de la virgen de la Cabeza (Andújar) y de la Fuensanta (Villanueva del Arzobispo) y los franciscanos de la virgen de Regla (Chipiona), aunque las crisis vocacionales han hecho que en algunos casos los hayan tenido que abandonar por no poder atenderlos.

Fueron las nuevas congregaciones dedicadas sobre todo a la enseñanza, como salesianos, escolapios, hermanos de La Salle, etc., que eran las instituciones más pujantes de la época, las que ocuparon muchos de los viejos conventos y sus iglesias, en las que introdujeron las devociones y santoral propio de los nuevos ocupantes, que vinieron a alterar o despiezar los programas iconográficos de los primitivos. Los salesianos recibieron el antiguo convento trinitario dedicado a las santas Justa y Rufina de la Trinidad, extramuros de la ciudad de Sevilla, en Utrera el antiguo convento carmelita calzado, en Morón de la Frontera el antiguo Hospital del Espíritu Santo y en Arcos de la Frontera el de los franciscanos descalzos. Los jesuitas el antiguo convento de san Francisco en el Puerto de 
Santa María y los Hermanos de La Salle de Sanlúcar de Barrameda el exconvento franciscano.

\section{Rituales: Semana Santa, vía crucis, rosarios, procesiones y rogativas}

La piedad barroca se manifestó en un amplio aparato ritual articulado en torno al culto al Santísimo Sacramento, Cristo en sus diversas advocaciones pasionistas, la Virgen en sus titulaciones dolorosas y gloriosas y diversos santos. La puesta en práctica de las disposiciones recogidas por el Concilio de Trento concedió un especial impulso a las celebraciones litúrgicas. Así a partir del siglo XVI se revitalizará la celebración de la Semana Santa a través de la fundación de cofradías de penitencia, que sacaban a la calle imágenes de la Pasión de Cristo y dramatizaciones pasionistas, que llenas de sentimiento y patetismo, buscaban mover a los fieles a la penitencia. De esta forma la Semana Santa y los desfiles procesionales de las cofradías, organizaciones de seglares cobijadas sobre todo por los conventos, constituyeron la quintaesencia de la religiosidad popular al procesionar los cristos y vírgenes en sus andas con su aparatoso acompañamiento de hermanos de luz, disciplinantes, figuras de romanos, personajes simbólicos y alegóricos, trompeteros, etc., que buscaban el mayor lucimiento estético posible en aras de conseguir el fin tan barroco de "mover a devoción" al espectador. No puede olvidarse que las primeras manifestaciones pasionistas se deben a los franciscanos que de acuerdo con su cristocentrismo promovieron las cofradías de la Vera Cruz pero que las demás órdenes, aunque en distinto grado, también siguieron. Así los dominicos promovieron las cofradías del Dulce Nombre de Jesús, los trinitarios las del Cautivo, los carmelitas y agustinos el Santo Sepulcro y estos últimos también el Cristo de Burgos. La rivalidad histórica entre ciertas cofradías pudiera estar vinculada a la ya existente entre las diversas órdenes religiosas de una misma localidad, recordamos ahora los casos de la cofradía de Jesús Nazareno o de Arriba, nacida en el seno del convento franciscano, y la cofradía del Dulce Nombre de Jesús o de Abajo alojada en el dominico en Antequera y lo mismo en Baena entre las del Nazareno fundada en el convento franciscano y la del Dulce Nombre en el dominico de Guadalupe.

Otra manifestación penitencial ampliamente difundida en la época fue la práctica del Vía Crucis. Aunque vinculados originalmente a los fran- 
ciscanos desde tiempos medievales por haber sido designados Custodios de los Santos Lugares de Jerusalén (1328) luego fueron diversas las órdenes religiosas que lo incorporaron sacralizando un espacio interno o externo del convento ${ }^{11}$. Se considera que este ritual nació en Córdoba hacia 1420 con el dominico Fray Álvaro de Córdoba, quien instaló cruces que marcaban el recorrido desde su convento de Scala Coeli hasta la capital; este ritual fue potenciado en Sevilla a comienzos del siglo XVI por el primer marqués de Tarifa a su regreso de la peregrinación a Tierra Santa, entre 1518 y 1520, fomentando la peregrinación al templete medieval de la Cruz del Campo. El número de estaciones quedó fijado en 12 que luego fueron 14 , señaladas por cruces o altares portátiles a lo largo del recorrido, con el que se quería recordar la distancia de los 1.321 pasos (997,13 metros) que separaban en Jerusalén la residencia de Pilatos del Monte Calvario. El ejemplo del humilladero sevillano trascendió pronto al resto de la región que vio llenar sus ciudades y pueblos de una variada y sugerente tipología de capillas callejeras, capillas-tribuna de gran personalidad estética como las de Antequera y Ronda ${ }^{12}$, calvarios, cruces de término, hornacinas y templetes que, al convertirse en escenarios de rituales y prácticas religiosas, impulsadas sobre todo por las órdenes religiosas, contribuyeron a la sacralización del entorno urbano. En la actualidad se conservan pocos de estos calvarios o vías sacra completos, aunque hay algunos muy señalados, como los de Huércal-Overa, Priego de Córdoba Zalamea la Real y La Puebla de Guzmán que se conservan en muy buen estado y están plenamente integrados en el casco urbano y en la vida religiosa y otros tantos con una ermita y algunas de las estaciones ${ }^{13}$.

${ }^{11}$ Sánchez López, J.A. y Ramírez González, S., "La capilla del Monte Calvario. Sitio histórico, realidad arquitectónica y patrimonio artístico", en: S. Rodríguez de Tembleque (coord.), El Monte Calvario. Historia, Arte y Devoción de Málaga, Málaga: Agrupación de Cofradías de Semana Santa, 2018, 95-98; Lazcano, R., "Dios en las afueras de la ciudad: El convento Santa María del Pópulo de Sevilla (1624-1835)”, Recollectio 42 (2017) 427-428.

${ }^{12}$ Ramírez González, S., "Las órdenes religiosas en la Ronda de la Edad Moderna. Implantación, proselitismo y testimonios iconográfico", Isla de Arriarán, no. 33 (2009) 3173.

${ }^{13}$ La existencia de ermitas, capillas y estaciones del viacrucis o al menos de los topónimos como "Monte Calvario", "Calvario" y menos frecuentemente "Sacromonte", es casi general en las poblaciones de Andalucía. Entre otros cabe citar el de Málaga, del que se conserva una capilla relacionada con los mínimos primero y con una cofradía después; Cas- 
Esta religiosidad se expresó también en otra modalidad de la espiritualidad andaluza del Barroco, como lo fueron los rosarios públicos, ampliamente extendidos por la región y que alcanzaron especial desarrollo en Sevilla a fines del siglo XVII gracias a la acción de la orden dominica, entre cuyos miembros destaca Fray Pedro de Santa María de Ulloa, considerado por la tradición popular como el promotor del rezo público del rosario y de su peculiar uso como procesión callejera. El siglo XVIII verá la consolidación de esta práctica religiosa mediante las agrupaciones rosarianas, que adoptan una compleja y diversa tipología en función de su naturaleza, lugar de residencia, fines, advocaciones, etc., y que se convierten en la tercera asociación parroquial junto a la Sacramental y la de Ánimas. Aunque también tuvieron gran protagonismo en la conformación de los rosarios públicos los capuchinos, entre ellos Fray Pablo de Cádiz, con sus misiones en la capital gaditana, Fray Isidoro de Sevilla, en la capital hispalense y Fray Feliciano de Sevilla, que crea en las parroquias las congregaciones del Santo Rosario, en las que se integraban hombres y mujeres, con unas breves constituciones ${ }^{14}$.

Parece que tuvo un origen distinto la devoción a la Virgen de la Aurora, nacida en el siglo XVIII previsiblemente en contraposición a la general práctica de rosarios de tarde y noche que, sobre todo desde las parroquias y conventos, salían por las calles de la localidad y que dieron lugar a la construcción de ermitas, algunas de gran valor arquitectónico, puestas bajo la advocación de esta denominación mariana y a unos rituales que tenían lugar durante la madrugada. Estas devociones no parecen tener relación directa con las órdenes religiosas, aunque sí indirectas pues fueron

tro del Río, del quedan algunas estaciones; y Puente Genil del que solo queda el registro histórico de una capilla hecha a semejanza de la de Jerusalén. En el convento de $N^{a}$. S ${ }^{a}$. del Populo de Sevilla el lego fray Eugenio de San Francisco, a su regreso de un viaje a los Santos Lugares en 1683, creó la Hermandad del Santo Sudario y Sepulcro de Cristo y construyó a imitación una capilla dedicada al Santo Sepulcro, cuyos hermanos tenían derecho de enterramiento en la misma. Cf. Rodríguez Becerra, S. y Hernández González, S., "Calvarios y Vía Crucis en la Provincia de Córdoba. Orígenes, evolución y manifestaciones artísticas", en: F. Labarga (Dir.), Camino del Calvario: rito, ceremonia y devoción. Cofradías de Jesús Nazareno y figuras bíblicas. Actas del Congreso Nacional bajo la advocación de Jesús Nazareno, Córdoba: Diputación Provincial 2016, 381-402.

${ }^{14}$ Romero Mensaque, C. J., El Rosario en Sevilla. Devoción, rosarios públicos y hermandades, Sevilla 2004. 
promovidas por la nobleza y burguesía locales en oposición a los rosarios promovidos desde conventos y parroquias. Una buena razón de ello es que estas ermitas solo se localizan en ciudades medias, donde más presencia y fuerza tenían este estamento y clase social, de ahí que fuera declarada patrona en algunas de ellas tales como Priego de Córdoba, Lucena, Montilla, El Puerto de Santa María, Fuentes de Andalucía o Grazalema, por solo citar algunas. En otros lugares ha desaparecido la ermita, pero ha quedado el topónimo, como ocurre en Ronda ${ }^{15}$.

Este panorama de expresiones rituales se completa con otras muestras más esporádicas e irregulares, como las fiestas y procesiones de acción de gracias organizadas en función de acontecimientos extraordinarios como canonizaciones, victorias militares, natalicios y bodas reales, así como las rogativas en coyunturas catastróficas como epidemias, sequías, inundaciones, etc., que ponen a prueba el poder taumatúrgico de las advocaciones cristíferas, marianas y hagiográficas en torno a las que se desenvuelve la religiosidad popular. Por otra parte, la participación en estos actos llevaba aparejada el ganar indulgencias que habían obtenido las órdenes religiosas de los papas.

\section{Devociones a las imágenes propias de las órdenes religiosas}

La devoción a la virgen María alcanzó en la Edad Media un nivel nunca logrado en el cristianismo. Esta situación de predominio que no fue exclusiva de España alcanzará altas cotas en los albores de la Edad Moderna en Andalucía, donde el culto a María no competía con otras devociones ya arraigadas, especialmente la de los santos, como ocurriera en los reinos cristianos del norte peninsular, lo que sin duda favoreció la difusión de su devoción. Buena prueba de ello es que las catedrales y parroquias principales de época medieval fueron puestas bajo la titularidad de Santa María, y en la Edad Moderna, las del reino de Granada, fueron situadas bajo el título de Encarnación. Así mismo en un tiempo incierto posterior

${ }^{15}$ Rodríguez Becerra, S., "La devoción a la Virgen de la Aurora y los rosarios públicos en Andalucía”, en: M. Peláez del Rosal (ed.), Las cofradías y hermandades del Rosario de la Aurora: historia, cultura y tradición, Córdoba: Asociación Amigos de Priego 2017, 115134. 
a la conquista cristiana surgieron numerosas ermitas por decisiones individuales o comunitarias, que por su carácter marginal estuvieron ajenas al interés eclesiástico, puesto que estaban en manos de santeros y ermitaños, hasta que cayeron también bajo su control designando para su visita a un alto eclesiástico de cada diócesis. Las órdenes religiosas, en claro proceso expansivo durante la Edad Moderna, fundaron sus conventos en muchas ocasiones sobre ermitas urbanas preexistentes y aunque fueron ajenas a la fundación de estos santuarios aprovecharon su existencia y devoción a las imágenes titulares de las mismas para incorporarlas a su panteón religioso, aumentando su influencia al convertirse en custodios de estos centros religiosos.

Las órdenes religiosas mendicantes a pesar de sus diferencias en los objetivos fundacionales puesto que cada una ponía el énfasis en un aspecto concreto: la predicación, el estudio, la pobreza, la vida contemplativa, la vida eremítica o urbana, la redención de cautivos o la hospitalización de los pobres, con el tiempo se fueron asemejando, de suerte que todas se hicieron urbanas y predicadoras, se organizaron internamente con instituciones parecidas, y desde luego, siguieron unas mismas estrategias de fidelización de los seglares: órdenes terceras, cofradías, indulgencias, enterramientos en sus iglesias. Ello, sin embargo, no impidió que insistieran en su propia singularidad formal y simbólica puesto que eran conscientes de la capacidad de cohesión de estas diferencias, intensificándolas mediante orígenes milagrosos, mitificando a sus fundadores, usando iconos religiosos rituales y símbolos exclusivos (escapulario, cordón, rosario, correa, escudo, colores, hábito, etc.), pero al tiempo eran conocedores de que ciertas formas de actuar habían dado resultados muy positivos. Téngase en cuenta que la competencia entre órdenes e incluso entre ramas de la misma orden era latente porque se disputaban los mismos segmentos de una sociedad, aunque al mismo tiempo se daba la colaboración en rituales, liturgias y catástrofes.

Las órdenes mendicantes y monacales, tanto las medievales (franciscanos, dominicos, carmelitas, agustinos, mercedarios, trinitarios, servitas y jerónimos) como las de tiempos modernos (mínimos, capuchinos y las ramas reformadas o descalzas de las antiguas), asumieron la devoción a María, le dedicaron una liturgia propia al tiempo que algunas la convirtieron en símbolo de la orden e incluso la declararon patrona con una advocación concreta. Así, los carmelitas pusieron la orden bajo la protección 
de la Virgen del Carmen que viste el hábito de la orden y su escapulario con el escudo de la misma que constituía el principal símbolo e, incluso, la consideran "fundadora" de la orden; los franciscanos se convirtieron en los adalides de la Inmaculada Concepción; los dominicos situaron en este sitio a la Virgen del Rosario y al Dulce Nombre de Jesús; los mercedarios erigieron como patrona a la Virgen de las Mercedes que resulta inconfundible porque viste el hábito de la orden y luce entre sus atributos el escudo de la misma y el escapulario; los trinitarios que tienen como patrona a la virgen del Buen Remedio, una imagen con niño, sedente o en pie, con la cruz bicolor en el pecho y en los escapularios; los servitas (Siervos de María) consiguieron extender la devoción de la virgen de los Dolores a través de las esclavitudes u organizaciones de seglares a pesar de que no contaron con conventos en Andalucía ${ }^{16}$. Hay que hacer la salvedad de que esta advocación es distinta de las imágenes marianas pasionistas o dolorosas presentes en la Semana Santa, aunque en algunos casos se han adaptado para asumir su salida procesional al recaer su cuidado en hermandades que las han rescatado para adoptarlas como titular.

Los agustinos tanto calzados como recoletos ${ }^{17}$ veneraban a su titular san Agustín y algunos santos propios de la orden como san Nicolás de Tolentino, santo Tomás de Villanueva y santa Mónica que mantienen una relativa presencia en el sistema de creencias de algunos sectores. Un caso aparte lo constituye el de santa Rita de Casia, monja agustina, cuya vida esta rodeada de maravillosismo que ha dejado una profunda huella en la religiosidad como abogada de las causas perdidas, aunque su devoción se mueve a niveles privados ${ }^{18}$. En cuanto a la vinculación mariana de esta orden no parece haber ocupado el primer lugar en su espiritualidad o al menos no se ha centrado en una sola advocación, aunque han predominado la virgen de la Consolación y Correa, así como del Socorro, la de Gracia y Buen Consejo, y también en la Inmaculada Concepción ${ }^{19}$. Parece estar más

${ }^{16}$ Hernández González, S., "Devociones marianas de gloria y órdenes religiosas en Andalucía”, en Advocaciones Marianas de Gloria, San Lorenzo del Escorial: Editorial Escurialense 2012, 107-120.

${ }^{17}$ Martínez Cuesta, A., Historia de los Agustinos Recoletos, vol. 1, Madrid: Editorial Augustinus 1995.

${ }^{18}$ Rodríguez Becerra, S., "Hagiografía y Milagros de una Santa Popular: Exvotos ofrecidos a Santa Rita en el convento de la Santísima Trinidad de Agustinas de Carmona", Lignum 4 (2015) 40-45. 
clara la vinculación con la figura de Cristo que en la advocación del Cristo de Burgos alcanzará gran renombre como milagroso en los más diversos lugares de España y sin duda los agustinos debieron tener responsabilidad en ello. Por su parte, la orden de los mínimos de san Francisco de Paula, que se establecieron en Málaga tras su conquista, tomó como protectora a la virgen de la Victoria, cuya devoción difundieron a través de sus conventos. La iconografía de la imagen, un tanto imprecisa la siguen las imágenes de todos los conventos puestos bajo la titularidad de esta advocación, actualmente casi desaparecida y ausente de culto salvo en la citada ciudad ${ }^{20}$. Finalmente, los capuchinos en el siglo XVIII divulgaron por todo el sur peninsular la devoción a la Divina Pastora, porque a fray Isidoro de Sevilla, gran predicador, le fuera inspirada en sueños la iconografía de María como pastora. Tiene una amplia presencia sobre todo en pintura y azulejos en iglesias.

Caso aparte merecen las órdenes monacales establecidas generalmente en monasterios en la mitad norte de la península desde tiempos medievales, relativamente aislados de las ciudades mientras que en Andalucía se establecieron solo algunas de ellas y siempre en emplazamientos cercanos a las grandes ciudades. Sin embargo, no hemos de olvidar que, como afirman todos los autores de repertorios marianos, las dos imágenes de María de mayor devoción en Castilla y Aragón hasta muy recientemente fueron la Virgen de Guadalupe y la Virgen de Montserrat, titulares de los santuarios que nacieron respectivamente en el monasterio jerónimo de Guadalupe y el benedictino de Montserrat. Interesa resaltar aquí al primero porque la devoción a la virgen de Guadalupe se expandió desde tiempos medievales por gran parte España, incluida la Andalucía del Guadalquivir en donde han quedado patronazgos y templos dedicados. Los frailes limosneros y personas autorizadas por el monasterio cacereño estaban legitimados para pedir limosna para la virgen de Guadalupe por toda la corona de Castilla, por lo que su devoción se extendió por gran parte de los reinos peninsulares y americanos, devoción que ha perdurado hasta los tiempos contemporáneos. Los jerónimos como orden monacal

${ }^{19}$ Benítez Sánchez, J. M., “Advocaciones marianas en la Orden de San Agustín”, en: F.J. Campos (coord.), Advocaciones Marianas de Gloria, San Lorenzo del Escorial: CERC 2012, 595-620.

${ }^{20}$ Romero Torres, J. L., "Iconografía de la Virgen de las Victoria en Andalucía. De la escultura religiosa a la imagen devocional", en: Los Mínimos en Andalucía, Almería: IEAAyuntamiento de Vera-Orden Mínima 2006, 497-538. 
de implantación exclusivamente hispánica tuvieron una importante presencia en Andalucía, donde erigieron soberbios monasterios en Granada, Córdoba y Sevilla. El de San Isidoro del Campo en Santiponce alcanzó gran notoriedad porque sus monjes los "isidros" fueron acusados de luteranismo por la Inquisición y perseguidos. Albergaron en sus conventos y difundieron imágenes de gran devoción en sus respetivas localidades, como la virgen de Gracia en Carmona y la virgen del Valle en Écija.

En cuanto a la posición de María en las órdenes mendicantes existieron diferencias muy marcadas entre ellas, así para los carmelitas como "Orden de Santa María del Monte Carmelo", la virgen del Carmen constituía el principal icono religioso hasta el punto de que dio nombre a la orden y la vistieron con el hábito de esta, la consideraban su "fundadora" y el escapulario se convirtió en un verdadero talismán. Los carmelitas crearon el mito de la expresa donación de la Virgen con la promesa de salvación a los que lo llevaran puesto y por supuesto cargaron la acción de indulgencias. La virgen del Carmen en la iconografía del Escapulario y el Purgatorio se expande en la Edad Moderna, por lo que a partir del siglo XVI "irrumpe con fuerza la devoción del Santo Escapulario con sus anexas gracias y privilegios, especialmente los que se refieren a la garantía de salvación y al privilegio sabatino, la devoción popular será desbordante, pero a la vez se apartará de su genuina devoción de origen como Madre de Cristo, Patrona, "Virgo Purísima"21.

Algo semejante ocurrió con la virgen de la Merced y la orden mercedaria redentora de cautivos que se implantó ampliamente en Andalucía gracias a que durante más de dos siglos fue frontera con los musulmanes granadinos y desde 1492 con los del norte de África. Esta advocación se constituyó en pilar fundamental de la orden y aunque las primitivas imágenes carecían de atributos gracias al "prestigio religioso, social y económico que la orden va alcanzado promueve la conciencia de su singularidad", se utilizan a partir del siglo XVI atributos específicos de la misma como los grilletes. La imagen sin niño viste desde entonces el hábito blanco de la orden y el escudo de esta, adquiriendo con el tiempo otros modelos iconográficos como los de madre de Dios y de la miseri-

${ }^{21}$ Martínez Carretero, I., "Origen de la advocación del Carmen y su expansión popular en Andalucía”, en: J. Aranda Doncel (coord.), Las advocaciones marianas de gloria, Córdoba: Cajasur 2003, 299-324. 
cordia, redentora de cautivos, comendadora, dolorosa e intercesora de las ánimas. La orden incluyendo los reformados descalzos se extendió por toda Andalucía fundando treinta conventos solo en la parte occidental ${ }^{22}$.

Otro tanto ocurrió con la orden de los Siervos de María o servitas, nacida en Italia, que adoptaron a la virgen de los Dolores como patrona, cuya fiesta celebraban el Viernes de Dolores y el culto ordinario se centraba en el rezo de la Corona Dolorosa todos los viernes del año, una especie de rosario compuesto por siete tramos que simbolizan los Siete Dolores de la Virgen. Estos frailes a pesar de que nunca fundaron conventos en la corona de Castilla expandieron su carisma, influencia y devoción a la virgen de los Dolores a través de su orden tercera, formada desde sus comienzos en el siglo XVIII por las élites urbanas y nobiliarias que crearon congregaciones en parroquias, conventos y capillas en muchas ciudades medias de Andalucía y que fueron desapareciendo en su mayoría a lo largo de los siglos XIX y XX y otras han continuado trasformadas en hermandades de penitencia. Algo semejante hicieron los dominicos que supieron aunar en el rosario los principales misterios de Jesucristo y la Virgen al que se añadió posteriormente las letanías lauretanas dedicadas exclusivamente a María. Estos utilizaron las parroquias para crear hermandades del Rosario bajo dependencia de la orden y en sus propios conventos lujosas capillas lujosas capillas adosadas y abiertas a la calle dedicadas a su patrona, para así acercar la devoción de esta advocación más al pueblo. También es de destacar la orden mercedaria que tiene en la virgen de la Merced una gran intercesora. Un menor peso tuvo la imagen de María entre franciscanos, centrados sobre todo en el cristocentrismo, aunque defendieron la Concepción Inmaculada de María y, desde luego, jesuitas, agustinos y trinitarios junto a otras órdenes religiosas.

Pero sin duda alguna las devociones marianas o cristíferas titulares de las órdenes religiosas que consideraban como propias junto a las de los santos de estas serán las que alcancen mayor arraigo por la acción de las respectivas órdenes. Hoy podemos contemplar altares dedicados a la Virgen del Carmen, del Rosario o la Inmaculada y menos a la de la Merced, de los Dolores, Victoria, Divina Pastora e Inmaculada por las iglesias pa-

${ }^{22}$ Ruiz Barrera, M. ${ }^{\mathrm{a}}$ T., "Notas iconográficas sobre la virgen de la Merced. Sus artes plásticas en Andalucía occidental", en: J. Aranda Doncel y R. de la Campa Carmona (coords.), Regina Mater Misericordiae, Córdoba 2016, 569-588. 
rroquiales y hasta no hace mucho tiempo veíamos a muchas mujeres portando los escapularios o hábitos carmelitas y desde luego, el rezo del rosario en diversos lugares es una aportación de los dominicos. El hábito morado que puede ser considerado un exvoto, ofrecido por los favores recibidos del Nazareno ha estado tan difundido hasta hace pocas décadas que era difícil llegar a una población y no encontrarse a una mujer u hombre con su vestido o camisa morados con cordón amarillo y este hábito no parece tener relación con ninguna orden religiosa.

Los dominicos y franciscanos son los principales responsables de la masiva presencia de advocaciones propias o adquiridas, seguidas de otras órdenes de menor presencia en la región, tanto en sus versiones de calzados y descalzos. Igualmente, las órdenes difundieron el culto a ciertos santos, sobre todos los específicos de cada orden. El santo cuya iconografía y devoción está más extendida es precisamente un franciscano, san Antonio de Padua o de Lisboa, canonizado en el siglo XIII en el primer año de su muerte. El campo de acción para esta difusión hagiográfica vino representado principalmente por los sermones y confesiones, misiones populares, conferencias cuaresmales y otras celebraciones en las que los predicadores fomentaban e impulsaban el culto del santoral propio de su orden. Esta propaganda desde el púlpito daba como fruto la creación de hermandades y cofradías a ellos dedicadas. En este sentido, los jesuitas, auténticos especialistas en la acción misional, difundieron el culto a san Ignacio de Loyola, san Francisco Javier, san Isidro Labrador y al Sagrado Corazón en sus campañas misionales por las comarcas de la costa granadina.

En no pocas ocasiones y por diversos motivos las órdenes religiosas competían dentro de cada localidad por la preeminencia, el poder y los beneficios que de ello se desprendían; para ello utilizaron las imágenes propias a las que postulaban como patronas o al menos que se votara una fiesta a su costa y para ello urdían estrategias para su reconocimiento por el concejo y el clero locales, logro que en ocasiones alcanzaban tras dura competencia con las postuladas por otras órdenes y linajes poderosos. Concretamente está documentado el duro forcejeo entre órdenes entre sí y con linajes oligárquicos por imponer el patronazgo de imágenes titulares de las órdenes y de especial devoción para alguno de ellos ${ }^{23}$. Estas imáge-

${ }^{23}$ En la ciudad de Jerez de la Frontera entraron en liza a comienzos de 1600 y con ocasión de una peste y sequía ciertos caballeros veinticuatros junto a los mercedarios par- 
nes han llegado a ser el referente religioso indiscutible de la población hasta el punto de que la mayoría de ellas fueron declaradas patronas por acuerdo de los concejos y la clerecía local, pues en este tiempo no se requería la aprobación papal24. Desde los conventos y su área de influencia los frailes y en ocasiones las monjas y las órdenes terceras extendieron la devoción a las imágenes con arraigo local o expandieron la devoción a las titulares de su orden respectiva.

\section{Predicaciones cuaresmales y en otros tiempos litúrgicos}

La palabra, que forma parte indisoluble de los rituales de todas las religiones, se constituye a veces en el centro de este, tal ocurre en la misa, en la que una parte esencial es la homilía, y en novenas, quinarios y triduos, así como en ceremonias mortuorias, de desagravio, rogativas y fiestas li-

tidarios de la virgen de la Merced o virgen negra con otros linajes y los dominicos devotos de la virgen de Consolación o virgen blanca, ambas consideradas patronas de la ciudad. El enfrentamiento se resolvió equitativamente acordando sendas fiestas costeadas por el cabildo a celebrar en los respectivos conventos en la fiesta de la Asunción de agosto y la Natividad de septiembre respectivamente (Sancho de Sopranis, H., Fiestas perpetuas votadas por la ciudad de Jerez de la Frontera desde el año 1600 a 1812, Jerez: Centro de Estudios Históricos jerezanos 1959,12-20). Otro tanto ocurrió en Carmona donde los dominicos y los partidarios de la virgen del Rosario compitieron para que la ciudad votara una fiesta en 1649 pero no lo consiguieron, favor que ya había conseguido la virgen de Gracia titular de los jerónimos (Rodríguez Becerra, S., "La Virgen de Gracia y Carmona: relaciones entre patrona y comunidad", en: J. M. ${ }^{a}$ Carmona Domínguez (ed.), La Virgen de Gracia de Carmona, Carmona: Hermandad de NSLS. Virgen de Gracia 1990,7). En Aracena de nuevo estuvieron presentes los dominicos que apostaron por san Blas, que recibía culto en su iglesia, el cual fue aprobado como patrono primero y principal de la ciudad por los cabildos civil y eclesiástico a finales del siglo XVII, seguido de San Sebastián y San Roque, dejando de lado a San Ginés, patrón de la viticultura, cf. Rodríguez Becerra, S. y Hernández González, S., "Religión y Religiosidad en la Sierra de Aracena", en: Actas XXV Jornadas de Patrimonio de la Comarca de la Sierra, Huelva: Diputación Provincial 2012, 157-265.

${ }^{24}$ A título de ejemplo valga citar el patronazgo de la virgen de la Victoria sobre la ciudad de Málaga, titular de los frailes mínimos; de la virgen del Rosario en la de Cádiz titular de los dominicos, de la virgen de la Merced sobre Jerez de la Frontera. Igualmente, la Virgen de Belén en Palma del Río, patrocinada por los franciscanos, la de Caños Santos en Cañete la Real por los franciscanos terciarios, Consolación de Utrera por los mínimos, la de Gracia de Carmona por los jerónimos y la virgen del Carmen en Grazalema y Prado del Rey en la sierra de Cádiz por los carmelitas. 
túrgicas. El sermón se constituye en la pieza clave de la oratoria sagrada; a través de él los frailes y clérigos adoctrinan, reconvienen, ensalzan y adaptan las fuentes sagradas a las realidades sociales y culturales de la época y los creyentes. Algunos de los sermones, especialmente los pronunciados por los grandes predicadores, mayoritariamente frailes, durante las fiestas señaladas y con ocasión de defunciones de personas reales y canonizaciones y episodios nacionales, se imprimían en cuadernillos. Estos se conservan por miles en las bibliotecas episcopales, de cabildos y universitarias y eran piezas habituales en las bibliotecas y archivos conventuales ${ }^{25}$, y previsiblemente en algunas casas. El sermón, figura central de la oratoria en este período, llegó a tales niveles de retórica y de retorcimiento del lenguaje, que quizás no sea acertado afirmar que fuera la mejor forma de adoctrinamiento del pueblo. El lenguaje utilizado, lleno de metáforas, giros y circunloquios, las continuas referencias al mundo bíblico y al mundo clásico y lo rebuscado del estilo, hacen muy improbable que fuera entendido, ni siquiera por el sector más cercano a la Iglesia del que formaban parte los caballeros, burgueses y funcionarios. Aunque sin duda alguna éstos últimos se sentirían atraídos por el espectáculo de oratoria que eran capaces de lograr los predicadores.

Las órdenes religiosas se habían ido especializando en la oratoria, de forma que en los siglos XVII y XVIII la mayoría de los predicadores eran frailes de las diversas órdenes. La predicación era una tarea básica en la concepción de la difusión de la religión y en consecuencia en la actividad conventual, en la formación de los novicios y en la carrera de los frailes. Tener un buen orador en un convento era asimismo una garantía de buenos ingresos y de prestigio para la orden. Por otra parte, la buscada y pregonada humildad de los frailes encontraba a nivel personal una íntima satisfacción y vanagloria. El fraile subido al púlpito era el centro de toda la atención de un público, numeroso y distinguido, que posteriormente vería su esfuerzo impreso "a solicitud de los aficionados" para mayor difusión y beneplácito de su autor; ello era sin duda expresión del poder dentro de la orden, de la importancia del convento y la vanidad de una elite de frailes, previsiblemente tan jerárquica como la propia sociedad a

${ }^{25}$ Antón Solé, P., "La religiosidad popular y su expresión plástica en los archivos de la Iglesia", en: Memoria Ecclesiae, vol. XVII, Oviedo: Asociación de Archiveros de la Iglesia 2000. 
la que servían y de la que se servían. Aunque quedan pocos testimonios escritos, no debemos de olvidar la labor catequética de los frailes legos que en su misión de limosneros realizaban entre criados y campesinos que asistían poco a los cultos. Aquellos recorrían la geografía rural del distrito conventual mostrando estampas y difundiendo las devociones de los santos de la orden y las advocaciones marianas propias, narrando los milagros y beneficios que se les atribuían y, en suma, dando cuenta de una forma de concebir la religión bien diferente a la de los teólogos, predicadores y maestros de las órdenes.

El canto a la humildad de los frailes, con frecuencia más deseo que realidad, se expresa también en las historias y crónicas de las órdenes, en las que se dice siempre que los grandes maestros rechazaban en primera instancia las mitras, a las que posteriormente accedían, en servicio de la orden y de la Iglesia. No debe minusvalorarse el poder y el prestigio del episcopado, pues a pesar de la influencia social de las órdenes, quienes detentaron el poder eclesiástico y espiritual fueron siempre los obispos y el alto el clero de las curias seculares. A este respecto, hay que tomarlo como un síntoma el hecho de que para las diócesis americanas se nombraban generalmente a frailes de las órdenes mendicantes simplemente porque el alto clero lo rechazaba. Sin duda alguna para un clérigo que deseaba hacer carrera, era preferible obtener una canonjía en una catedral o cualquier otro beneficio eclesiástico en la península que una mitra en un lejano y generalmente pobre territorio americano.

\section{Las instituciones: Hermandades, cofradías, órdenes terceras y rosarios públicos}

Las hermandades y cofradías son instituciones canónicas de seglares surgidas con el propósito religioso de dar mayor realce y permanencia al culto de determinadas imágenes y a la expiación de culpas, y a la vez cumplir otras funciones sociales de carácter asistencial, defensa de grupos o etnias, así como de apoyo mutuo. Su variedad y diversidad, tanto en su estructura como en su composición y objetivos, ha sido tan diversa y cambiante que resulta difícil establecer unos denominadores comunes. Son características básicas a todas ellas el ser asociaciones de seglares, autorizadas por el ordinario, que dan culto especial a una o varias imágenes titulares en altares y 
capillas parroquiales, iglesias conventuales, capillas y ermitas, tienen personalidad jurídica y por tanto poseen bienes muebles e inmuebles independientes de los eclesiásticos. Han constituido en todo tiempo, no exento de diferencias y desencuentros, un apoyo a la institución eclesiástica y a las órdenes religiosas a las que subvenían con recursos económicos como pago a los actos litúrgicos y donativos. Han formado, asimismo, parte del entramado de dominio y adoctrinamiento permanente de los fieles.

Las órdenes religiosas, en especial las mendicantes, durante todo el Antiguo Régimen se distinguieron por su promoción de las hermandades y cofradías de pasión, pues "las características propias de las órdenes religiosas, cercanas a los sentimientos populares tanto por sus actividades de carácter asistencial, como por las peculiaridades de sus acciones pastorales, en concreto de su predicación, las sitúan en una posición muy cercana a las asociaciones pasionistas"26. En esta línea hay que destacar la labor ejercida por los franciscanos en la difusión de la devoción a la Vera Cruz por todo el occidente cristiano. Esta semilla germinará en los conventos de la orden seráfica a través de la creación de las cofradías de la Santa Vera Cruz, que por lo general suelen ser las más antiguas en las poblaciones andaluzas. Dedicadas en principio al culto como fin primordial, se convierten en penitenciales en la transición del siglo XV al XVI y llegan a la época del barroco configuradas como cofradías de estricto sentido pasionista que, la efervescente espiritualidad de la Contrarreforma, dará lugar a una diversa tipología cofrade: gremiales, nobiliarias, de caridad, votivas, devocionales, congregaciones religiosas o espirituales, y corporaciones propiamente penitenciales, al tiempo que cobran especial impulso la devoción al Santo Rosario, la Concepción de María, el culto a la Vera Cruz, Santísimo Sacramento y Ánimas del Purgatorio.

El siglo XVII representa la época dorada para las cofradías, pues al estar integradas por laicos y nacidas con fines religiosos y asistenciales, y establecidas en conventos, parroquias y ermitas, fueron forjando un tejido religioso en el que el seglar jugaba un importante papel $^{27}$. La principal

${ }^{26}$ Fernández Basurte, F., La procesión de Semana Santa en la Málaga del siglo XVII, Málaga: Universidad de Málaga 1998, 159.

${ }^{27}$ Pascua Sánchez, Ma . J. de la, "Solidaridad en el Antiguo Régimen. Las hermandades", Andalucía en la Historia, n ${ }^{\circ} 15$ (2007) 17 - 21; Lara Ródenas, M. J., "La sociabilidad religiosa en la Andalucía del Antiguo Régimen”, Demófilo, n ${ }^{\circ} 23$ (1997) 15-42. 
proyección social de las cofradías, aparte de la labor asistencial, era realzar los días de fiesta por medio de solemnes funciones religiosas y sobre todo procesiones (sacramentales, penitenciales y vías sacras, marianas y rosarianas) y romerías con las que se jalonaban los días feriados. La mayoría de las cofradías de pasión surgen y se desarrollan en las iglesias conventuales, apoyadas y alentadas por el clero regular, mientras que en las parroquias el fenómeno se produce con mucha menor intensidad salvo las de obligada presencia instadas por las diócesis, es decir las del Santísimo Sacramento y las de las Ánimas del Purgatorio. En cambio, en las iglesias conventuales se establecen claras asociaciones y vinculaciones entre determinadas advocaciones y las órdenes religiosas. Así, junto a la ya apuntada relación entre los franciscanos y la Vera Cruz, las del Santo Entierro y la Soledad en los conventos de agustinos, carmelitas y dominicos, no debe olvidarse la implicación del clero regular en el impulso de las hermandades dedicadas a la nueva devoción de Jesús Nazareno, que cobra especial auge a partir del último tercio del siglo XVI y mitad de la siguiente centuria, aunque en Sevilla se registran fundaciones en el Setecientos, especialmente en ámbitos parroquiales ${ }^{28}$.

Para las órdenes religiosas la creación y desarrollo de estas corporaciones pasionistas supone una serie de beneficios que incitan a los frailes a la promoción y protección de estas asociaciones de fieles. En primer lugar, la importancia de estas agrupaciones penitenciales como cauce para la vivencia religiosa es aprovechada por las órdenes para extender e intensificar las prácticas religiosas. Así, los cultos, las misas, las procesiones e incluso los propios entierros son momentos a los que solía concurrir un importante número de fieles, ocasiones que se aprovechaban por los pre-

${ }^{28}$ Aranda Doncel, J., "Las cofradías de Jesús Nazareno en Andalucía durante los siglos XVI al XIX", Boletín de la Real Academia de Ciencias, Bellas Letras y Nobles Artes, $\mathrm{n}^{\circ} .140$ (2001) 173-196; Martín Riego, M., "Las hermandades de Jesús Nazareno en la archidiócesis de Sevilla en el siglo XVIII", en: Actas del Congreso Internacional Cristóbal de Santa Catalina y las cofradías de Jesús Nazareno, Córdoba 1991, 371; Sánchez Herrero, J.; López Bahamonde, M. del R.; Miura Andrades, J. M.; Montes Romero; Camacho, I., "Los cuatro tipos diferentes de Cofradías de Semana Santa, desde su fundación hasta la crisis de finales del siglo XVIII en la Andalucía bética y Castilla”, en: Actas del I Congreso Nacional de Cofradías de Semana Santa, Zamora 1987,259-303; Domínguez Ortiz, A. y otros, La Sevilla de las Luces con las respuestas y estados generales del Catastro de Ensenada, Sevilla: Ayuntamiento de Sevilla 1991. 
dicadores para la difusión de la doctrina desde el púlpito. En segundo lugar, el fuerte atractivo devocional que poseen algunas imágenes genera un constante flujo de fieles a sus capillas, lo que determina una vida intensa en las iglesias conventuales. Este movimiento de cofrades y devotos beneficia a la comunidad conventual tanto en el plano espiritual como en otros aspectos, sobre todo en el económico, no solo a través del incremento de limosnas, donativos, etc., sino también a través de la percepción de estipendios por la celebración de los actos de culto de la cofradía, participación corporativa en la procesión de Semana Santa, asistencia a los entierros de los hermanos y misas en sufragio del alma de los cofrades fallecidos. Tales contraprestaciones entre cofrades y clero regular quedan reguladas por escrito en los acuerdos a los que llegan las comunidades con las hermandades, de los que podrían citarse innumerables ejemplos, muy expresivos de estas estrechas relaciones entre cofradías y conventos. Y en un último plano, en el que se mezcla lo económico y lo espiritual, habría que referirse a las ventas a las cofradías, por parte de las comunidades conventuales, de terrenos destinados a la construcción de capillas y camarines para el culto de sus imágenes, lo que generaba un juego de intereses mutuos: los cofrades gozan de un espacio en el que desenvolver su vida corporativa con cierta autonomía, y los religiosos obtienen la garantía de que estos recintos se van a mantener siempre en condiciones óptimas para un culto constante, al garantizarse su cuidado, adorno y enriquecimiento gracias a las aportaciones de la propia cofradía y las donaciones de los fieles. En otros casos, esta expansión del número de cofradías desborda el marco del propio templo conventual, al instalar sus imágenes en otras capillas levantadas en los claustros, porterías y huertas conventuales.

Las órdenes terceras constituyen agrupaciones de laicos vinculados a una orden religiosa que adoptan, desde su condición de seglares, la espiritualidad, las formas y los beneficios espirituales de la orden a la que se adscriben. En todas las órdenes religiosas los varones constituían la primera orden, las mujeres la segunda y los laicos la tercera. Esta constituía una fórmula para vivir la espiritualidad de la orden, beneficiándose de sus gracias y privilegios espirituales, pero sin abandonar el mundo y en los siglos primeros incluso disfrutaban del fuero eclesiástico y al tiempo era una forma de fidelizar a los seguidores en un mundo donde competían tantas órdenes. La pertenencia a una orden tercera constituía por tanto una vía de perfección espiritual en la que el individuo, sin dejar su estado, 
participaba a través de una vida austera y penitente -incluso con el uso del hábito- en los valores de la orden en cuestión a través de una serie de normas de vida y actividades de culto minuciosamente reguladas en las Reglas por las que estos terciarios se regían. Esta oferta se apoyaba además en los privilegios espirituales que las órdenes primeras lograban de los papas que ofrecían a sus seguidores en competencia con los de otras órdenes ${ }^{29}$. Estas alcanzaron en Andalucía especial importancia en el caso de la orden franciscana, siendo habitual que en cada convento seráfico estuviese erigida la Venerable Orden Tercera, la cual contaba con capilla propia donde realizar los ejercicios y actividades propios de su instituto, entre los que fue muy característico el culto al Santísimo Sacramento. Los miembros de las órdenes terceras, pero también otros muchos seglares eran amortajados a la hora de la muerte con el hábito de la orden a la que se sentían unidos, destacando sobre todo la de san Francisco, con el que se enterraban en Cádiz en el siglo XVIII dos tercios de sus habitantes; otros movidos por su devoción, filiación y posibilidades económicas se hacían enterrar en los propios conventos ya fuese en alguna capilla -la mayor se reservaba a los patronos- o en otras dependencias conventuales entrando así en competencia con los cementerios parroquiales ${ }^{30}$.

Por último, es preciso referirse a la tradición religiosa del rosario de la Aurora que ha perdurado de forma generalizada en las parroquias hasta la segunda mitad del siglo XX y de la que quedan muestras muy representativas ya sea de la hermandad o congregación como de los que despertaban a sus hermanos con sus cantos e instrumentos conocidos como auroros, que en algunos casos son los que han mantenido la tradición. Aunque en el pasado esta manifestación de piedad se localizaba en casi toda España han quedado escasas muestras institucionalizadas de esta actividad religiosa. En Andalucía son de destacar los rosarios de la Aurora, campanilleros y los auroros de Priego de Córdoba y otros núcleos de la Subbética cordobesa, así como los de Arriate, Aracena y Riotinto (conocida como la Esquila), entre otros muchos. Estos rosarios públicos o ca-

${ }^{29}$ Rodríguez Becerra, S., "Los privilegios espirituales de la Orden Tercera de San Francisco", en: M. Peláez del Rosal (ed.), El franciscanismo en Andalucía. La orden Tercera seglar, Córdoba: Asociación Hispánica de Estudios Franciscanos 2006, 457-474.

${ }^{30}$ Pascua Sánchez, M. ${ }^{a}$ J. de la, Vivir la muerte en el Cádiz del Setecientos (1675-1801), Cádiz: Ayuntamiento 1990; Morgado García, A., La diócesis de Cádiz: de Trento a la desamortización, Cádiz: Universidad de Cádiz 2008. 
llejeros en Andalucía fueron creación del dominico fray Pedro de Santa María de Ulloa que los inició en el convento sevillano de San Pablo a finales del siglo XVII y que se institucionalizaron en la centuria siguiente ya como hermandades del Rosario, sobre las que tenían el monopolio los dominicos, $\mathrm{u}$ otras advocaciones marianas. Las procesiones iban encabezadas por un estandarte de la virgen del Rosario, acompañado por grandes faroles y seguidos por los devotos de la parroquia o parcialidad que cantaban y rezaban el rosario, mientras recorrían las calles de las ciudades durante la tarde, la noche o al amanecer o aurora. Tanto se expandió el rosario por toda la geografía andaluza que llegaron a existir varios rosarios en un mismo distrito parroquial sobre la base de distintas imágenes marianas existentes en conventos, ermitas, hornacinas y parroquias, puestas bajo diversas advocaciones, aunque predominaron las del Rosario propiamente dicho. Esta abundancia dio lugar a pendencias por protocolo hasta el punto de que los poderosos se separaron de la corriente general creando sus propias capillas de la Aurora. De estas quedan numerosos casos en las ciudades medias andaluzas, en otras solo el recuerdo toponímico. Para la Virgen de la Aurora se creó una nueva iconografía mariana: imagen sedente con niño y lábaro de plata ${ }^{31}$. Por todo ello, los rosarios públicos, incentivados una vez más por las órdenes religiosas, pueden considerarse como una de las expresiones más genuinas de la religiosidad andaluza hasta el último tercio del siglo $\mathrm{XX}^{32}$.

${ }^{31}$ Rodríguez Becerra, S., "La devoción a la Virgen de la Aurora y los rosarios públicos en Andalucía", en: M. Peláez del Rosal (ed.), Las cofradías y hermandades del Rosario de la Aurora: historia, cultura y tradición, Córdoba: Asociación Amigos de Priego 2017, 115134.

${ }^{32}$ Romero Mensaque, C. J., El Rosario en la provincia de Sevilla, Sevilla: Diputación de Sevilla 2010. 